\title{
Pengembangan Media Big Book Untuk Meningkatkan Kemampuan Literasi Anak Usia 5-6 Tahun
}

\author{
Gunanti Setiyaningsih, Amir Syamsudin \\ gunanti0258pasca2016@student.uny.ac.id, amirsyamsudin@uny.ac.id \\ Pascasarjana Universitas Negeri Yogyakarta
}

Developing Big Book Media For Improving Literacy Ability To Children Of 5-6 Years Old

\begin{abstract}
This study aimed to develop a big book media based on fieldwork, needs analysis, and the study of literature in kindergarten. This research and development is adopting the model of Borg \& Gall with the stages consisting of: (1) research and information collecting, (2) planning, (3) developing the preliminary form, (4) preliminary filed testing, (5) main product revision, (6) main filed testing, (7) operational product revision, (8) operational field testing, and (9) final product revision. The subjects of the preliminary field test was one class, and those for field test were five classes. The subjects of the operational testing were eleven classes. The data was collected through interviews, validation product, observation, and questionnaires. The data analysis technique used was inter-rater reliability and Cohen's Kappa with SPSS program version 22. The result of the research was the big book media and its guide book that consisted of introduction, basic competencies and indicators, steps of using the media, and daily activity plan. The result of material expert showed that the material was in a sufficient category. The result of media expert showed that the media was excellent. The result of preliminary field test, field test, and operational test were valid according to Aiken validity. The agreement of teachers in field test with Kappa coefficient value showed $50 \%$ or moderate. The agreement of teachers in operational test with Kappa coefficient value showed 51,78\% or moderate. The literacy ability of children at operational test improved well.
\end{abstract}

Keywords: Big Book Media, Literacy Ability, 5-6 Years Old Children

Received date: 29 Juli 2018

Article Info

Revised date: 8 Januari 2019

Accepted date: 22 Januari 2019

\section{PENDAHULUAN}

Pendidikan anak usia dini merupakan wahana pendidikan yang memberikan kerangka dasar dalam membentuk dan mengembangkan dasar-dasar pengetahuan, sikap dan keterampilan anak. Pendidikan ini bertujuan untuk mengembangkan seluruh potensi yang ada pada diri anak dan diharapkan anak dapat menjadi manusia yang seutuhnya. Oleh karena itu, memberikan rangsangan yang tepat sangat penting dilakukan. Rangsangan tersebut harus dapat mengembangkan seluruh aspek perkembangan yang dimiliki anak secara keseluruhan termasuk aspek kognitif, bahasa, sosial emosional, fisik motorik, seni, nilai agama dan moral. Salah satu perkembangan yang perlu distimulasi adalah perkembangan bahasa.

Bahasa merupakan pondasi perkembangan literasi. Literasi anak usia dini melibatkan kesadaran dasar dan pemahaman bahasa (Biddle, Nevarez, Henderson, Kerrick; 2014). Dengan literasi yang berkembang optimal maka anak dapat menguasai kemampuan membaca dan menulis pada tingkat selanjutnya. Mengingat pentingnya literasi pada anak usia dini, hendaknya komponenkomponen yang mampu menunjang penguasaan literasi di Taman Kanak-Kanak harus terus dikembangkan. Salah satu komponen penunjang yang dimaksud adalah penggunaan media dalam meningkatkan kemampuan literasi anak. Hal ini sesuai dengan pendapat Flewitt (2011) yang menyatakan bahwa kesiapan anak dalam mencapai perkembangan literasi membutuhkan berbagai macam media.

Berdasarkan hasil penyebaran angket tentang pembelajaran literasi anak usia 5-6 tahun di TK se-Kecamatan Bambanglipuro didapatkan hasil bahwa pembelajaran literasi yang berlangsung selama 
ini belum berjalan optimal. Hal ini dapat diketahui dari metode yang digunakan dalam pembelajaran literasi belum bervariasi. Metode yang banyak digunakan adalah metode tanya jawab, bercerita dan pemberian tugas. Metode tersebut sering digunakan sehingga banyak anak yang kurang tertantang dengan pembelajaran literasi yang terjadi. Selain itu, media yang digunakan dalam pembelajaran literasi masih monoton. Pendidik banyak menggunakan media kartu huruf dalam pembelajaran literasi. Media kartu huruf yang sering digunakan akan membuat anak bosan dalam pembelajaran literasi.

Berdasarkan kenyataan yang telah dipaparkan tersebut maka media untuk pembelajaran literasi perlu dikembangkan sebagai salah satu cara untuk mengoptimalkan kemampuan literasi anak di TK se-Kecamatan Bambanglipuro. Media yang diperlukan adalah media yang menarik dan menyenangkan bagi anak. Penggunaan media dalam kegiatan belajar akan membantu menarik anak untuk belajar sehingga motivasi belajar anak meningkat. Sadiman (2014) menjelaskan media adalah segala sesuatu yang dapat digunakan untuk menyalurkan pesan dari pengirim ke penerima sehingga dapat merangsang pikiran, perasaan, perhatian dan minat serta perhatian anak sedemikian rupa sehingga proses belajar terjadi. Salah satu media yang dapat digunakan adalah media big book. Normaliza dan Nik (2010) menyatakan penggunaan big book dapat menciptakan konteks pembelajaran yang kondusif karena anak memiliki kesempatan untuk berinteraksi lebih banyak dengan guru dan teman sebayanya. Big book menjadi favorit bagi semua mata pelajaran. Dengan demikian penggunaan big book dapat menumbuhkan pembelajaran yang menyenangkan bagi anak sehingga kemampuan literasi anak berkembang optimal.

\section{KAJIAN PUSTAKA}

\section{Media Big Book}

Media merupakan sarana yang digunakan untuk menyampaiakn pesan. Boove (1997) menjelaskan media merupakan sebuah alat yang mempunyai fungsi menyampaikan pesan. Sependapat dengan Boove, Heinich (1996) mengemukakan media adalah saluran komunikasi, berasal dari kata Latin yang berarti "antara" kata ini mengacu pada sesuatu yang membawa informasi antara pengirim pesan kepada penerima pesan. Contohnya seperti film, televisi, diagram, buku, komputer dan instruktur. Salah satu media adalah big book. Big book adalah buku bacaan yang memiliki ukuran, tulisan dan gambar yang besar. Berdasarkan pendapat Tompkins \& Hoskisson (1995), big book adalah buku bergambar yang ukurannya sangat besar dan dipakai guru dalam kegiatan membaca bersama. Hal yang sama diungkapkan Jalongo (2007), big book artinya buku bergambar berukuran besar yang dipakai untuk demonstrasi membaca. oleh Brown (1980), big book adalah buku dengan ukuran besar dan ilustrasi penuh warna yang digunakan guru untuk menyampaikan cerita dalam suatu kelas.

Berdasarkan pendapat Suyanto (2007), big book merupakan media yang disenangi anak-anak dan dapat dibuat sendiri oleh guru. Buku dengan ukuran besar ini biasanya untuk anak kelas rendah. Didalamnya ditulis wacana sederhana, singkat dengan huruf besar dan diberi atau ditempeli gambargambar berwarna. Anak-anak sambil membaca atau mendengarkan cerita, anak-anak juga melihat gambar-gambar yang dibuat berwarna dengan ukuran cukup besar agar penggunaannya lebih komunikatif dan mudah dilihat oleh anak. Big book untuk tujuan memperkenalkan tata bahasa dan kosakata dapat dikemas dalam bentuk cerita. Pola-pola kalimat tertentu dalam cerita sebaiknya diulang-ulang agar anak menjadi biasa mendengarkannya. Dengan ukuran yang besar serta bentuk yang disertai gambar akan membuat anak lebih konsentrasi dalam pembelajaran literasi. Adapun ciriciri big book berdasarkan pendapat Karges-Bone (1992) adalah alur cerita singkat (10-15 halaman), pola kalimat jelas, gambar memiliki makna, jenis dan ukuran huruf jelas terbaca dan jalan cerita mudah dipahami. Hal lain diungkapkan oleh Solehuddin (2014) adalah berukuran kurang lebih $40 \mathrm{~cm}$ x $60 \mathrm{~cm}$, merupakan buku cerita yang berkarakteristik khusus yang dibesarkan teks dan gambarnya, penuh warna warni, memiliki kata yang dapat diulang-ulang, mempunyai alur/ plot cerita yang mudah ditebak dan memiliki pola teks yang berirama untuk dapat dinyanyikan atau dibunyikan. Keistimewaan big book (Yaacob \& Pinter, 2008) adalah big book meningkatkan partisipasi dan keaktifan anak dalam belajar dan big book meningkatkan motivasi dan ketertarikan anak.

\section{Pembelajaran Literasi Anak}

Pembelajaran merupakan kombinasi yang tersusun dari unsur-unsur manusiawi, material, fasilitas, perlengkapan dan prosedur yang saling mempengaruhi untuk mencapai tujuan pembelajaran 
(Meyer, 2008). Gagne dan Briggs (1979) menyatakan pembelajaran merupakan sistem yang bertujuan membantu proses belajar anak, yang berisi serangkaian peristiwa yang dirancang sedemikian rupa untuk mempengaruhi dan mendukung terjadinya proses belajar siswa yang bersifat internal. Pembelajaran (Jamaris, 2006) adalah suatu kegiatan yang mencakup kegiatan belajar dan mengajar.

Berdasarkan pendapat Brewer (2014), literasi berarti kemampuan membaca dan menulis untuk memecahkan masalah, memenuhi kebutuhan seseorang, mempelajari informasi baru dan menemukan kesenangan dalam kata-kata tertulis. Pilgrim \& Martinez (2015) menyatakan literasi adalah membaca dan menulis secara efektif dalam konteks yang bervariasi. Mena \& Eyer (2009) literasi adalah kemampuan mendengar dan berbicara dan akhirnya dapat membaca dan menulis yang dimulai pada awal dan pengalaman sehari-hari. Pembelajaran literasi (Goodman, etc. 1986) bukan hanya belajar membunyikan dan menuliskan huruf-huruf dengan cara merangkai-rangkainya melainkan upaya mengembangkan kemampuan literasi (dengar-cakap-baca-tulis) yang berdasar pada kemampuan berbahasa.

\section{Kemampuan Literasi Anak}

Kemampuan literasi pada anak ada sejak lahir. Hal ini sesuai pendapat French (2013), literasi dimulai sejak bayi belajar bahasa dan mengenal buku. Proses ini berlanjut sampai anak usia dini. NAEYC juga menyatakan bahwa usia lahir sampai 8 tahun merupakan masa paling penting untuk perkembangan literasi anak. Papalia (2009) mengungkapkan literasi sebagai kemampuan untuk membaca dan menulis. Jadi kemampuan literasi adalah kemampuan anak dalam mengenal kata dan tulisan serta anak mampu memaknai kata atau tulisan tersebut.

Perkembangan awal literasi pada anak akan mempengaruhi ketercapaian literasi selanjutnya. Berdasarkan pendapat Musfiroh (2009), literasi berkembang dari utuh ke bagian secara fungsional, bermakna, relevan dengan penggunaan bahasa. Prinsip literasi berdasarkan pendapat Musfiroh (2009) adalah kemahiran dalam keterlibatan yang fungsional, menjalin dalam diri anak untuk mengkonstruksi konsep huruf, kata dan kalimat tertulis serta memahirkan kemampuan riversibility dan konservasi dalam membaca dan menulis.

Selama 5 tahun pertama, anak-anak mencapai perkembangan mulai memahami bentuk huruf, setiap kata memiliki makna, anak menghubungkan kata dengan suara, mulai mengenal tulisan yang ada dilingkungannya, mulai membedakan menggambar dan menulis serta huruf dan angka, anak belajar menghubungkan buku dengan membaca dan anak membaca dengan senang hati (Gonzalez, J \& Mena, 2011). Kemampuan literasi yang dapat dikembangkan pada anak usia dini berdasarkan pendapat Biddle, Nevarez, Henderson, Kerrick $(2014,333)$ adalah mengenal huruf-huruf alfabet, mengenal 20 huruf dan bunyinya, mulai memiliki kesadaran fonemis (setiap kata memiliki unsur bunyi), mulai membaca dan menulis kata-kata kosonan-vokal-konsonan yang sederhana dan mampu mengenali beberapa kata-kata sederhana.

\section{Anak Usia 5-6 Tahun}

Anak usia 5-6 tahun berada pada tahap operasional. Berdasarkan pendapat Suyanto (2005), pada tahap ini anak mulai menunjukkan proses berpikir yang jelas. Anak mulia mengenali beberapa simbol dan tanda termasuk bahasa dan gambar. Penguasaan abhasa anak sudah sistematis, anak dapat melakukan permainan simbolis. Hal yang hampir sama diungkapkan oleh Santrock (2007), anak mulai merepresentasikan dunianya dengan kata-kata, bayangan dan gambar-gambar. Anak mulai berpikir simbolik, pemikiran-penikiran mental mucul, egosentrisme tumbuh dan keyakinan magis mulai terkonstruksi. Berkaitan dengan hal tersebut maka diperlukan pembelajaran yang diarahkan untuk mengembangkan kemampuan berkomunikasi dan literasi.

\section{METODE PENELITIAN}

Penelitian ini merupakan jenis penelitian dan pengembangan (Research and Development). Penelitian ini menghasilkan media big book untuk meningkatkan kemampuan literasi anak usia 5-6 tahun. Penelitian pengembangan adalah suatu proses yang dipakai untuk mengembangkan dan memvalidasi produk pendidikan. Produk yang dihasilkan melalui tahap validasi dari beberapa ahli dibidangnya dan uji coba produk. Uji coba produk dilakukan dengan tujuan untuk mengetahui apakah media big book yang dikembangkan layak digunakan untuk pembelajaran literasi anak usia 5-6 tahun. Uji coba produk pada uji lapangan awal adalah 1 kelas kelompok B TK KKLKMD Sedyo Rukun. Uji coba produk pada uji lapangan utama adalah 5 kelas kelompok B (TK Pertiwi 51 Tulasan, TK Al 
Pengembangan Media Big Book Untuk Meningkatkan Kemampuan Literasi Anak Usia 5-6 Tahun (Gunanti Setiyaningsih, Amir Syamsudin)

Hidayah Sumbermulyo, TK ABA Mulyodadi IV Belan, TK Santi Bahagia dan TK Kanisius Immaculata I). Uji coba produk pada uji lapangan diperluas dilakukan pada 11 kelas kelompok B ( TK LKMD Ngambah, TK ABA Sidomulyo II, TK ABA Sumbermulyo V, TK LKMD Sidomaju, TK ABA Mulyodadi I Pete, TK ABA Derman, TK ABA Mulyodadi II Sribit, TK Tabitha, TK ABA Sidomulyo I, TK LKMD Trowolu dan TK ABA Jogodayoh I).

Pengumpulan data dilakukan melalui wawancara, validasi produk, observasi dan angket. Instrumen pengumpulan data yang digunakan dalam penelitian ini antara lain instrumen validasi produk untuk ahli materi dan ahli media serta angket respon guru terhadap media big book yang dibuat. Analisis data yang digunakan adalah inter-rater reability dan Cohen's Kappa dengan program SPPS versi 22.

\section{HASIL PENELITIAN DAN PEMBAHASAN}

\section{Hasil Penelitian}

Berdasarkan langkah penelitian dan pengembangan yang mengadaptasi langkah Borg \& Gall (1983), penelitian yang dilakukan mendapatkan hasil sebagai berikut

\section{Hasil Validasi Ahli Materi}

Validasi materi dilakukan untuk memperoleh kevalidan materi. Validasi materi media big book ini adalah dosen Pasca Sarjana Prodi Pendidikan Dasar Universitas Negeri Yogyakarta yaitu Dr. Enny Zubaidah, M.Pd. Berdasarkan tabel 4 dapat disimpulkan bahwa media big book pada aspek materi memiliki validitas Aiken yang cukup valid. Penilaian validator terhadap materi dalam media big book yang dikembangkan oleh peneliti secara keseluruhan dapat disimpulkan cukup baik.

Tabel 1. Hasil Validasi dari Ahli Materi Literasi

\begin{tabular}{|c|c|c|c|}
\hline No & Indikator & Validitas Aiken & Kesimpulan \\
\hline 1 & Media big book memuat huruf alfabet & 0.5 & Cukup valid \\
\hline 2 & Media big book mengenalkan bunyi huruf alfabet & 0.5 & Cukup valid \\
\hline 3 & Media big book memuat bunyi suku kata & 0.5 & Cukup valid \\
\hline 4 & Media big book memuat kata konsonan-vokal-konsonan & 0.75 & Valid \\
\hline 5 & Media big book memuat kata-kata sederhana & 0.5 & Cukup valid \\
\hline
\end{tabular}

\section{Hasil Validasi Ahli Media}

Ahli media me-review produk media big book dari aspek kelayakan isi, aspek kebahasaan, sajian, kegrafisan dan cover. Hal ini dilakukan agar hasil produk media layak dan adaptable untuk diterapkan dalam pembelajaran literasi secara empiris. Validasi media dilakukan oleh dosen Pascasarjana Universitas Negeri Yogyakarta yaitu Dr. Sujarwo, M.Pd.

Tabel 2. Hasil Validasi Ahli Media pada Aspek Kelayakan Isi

\begin{tabular}{clcc}
\hline No & \multicolumn{1}{c}{ Indikator } & Validitas Aiken & Kesimpulan \\
\hline 1 & Kesesuaian isi big book dengan indikator pembelajaran literasi & 1 & Valid \\
\hline 2 & $\begin{array}{l}\text { Kesesuaian isi big book dengan pembelajaran literasi anak usia 5-6 } \\
\text { tahun }\end{array}$ & 0.75 & Valid \\
\hline 3 & $\begin{array}{l}\text { Kesesuaian isi big book dengan kebutuhan media pembelajaran } \\
\text { literasi }\end{array}$ & 0.75 & Valid \\
\hline 4 & Kebenaran substansi materi literasi anak usia 5-6 tahun & 1 & Valid \\
\hline 5 & $\begin{array}{l}\text { Manfaat untuk pengembangan kemampuan literasi anak usia 5-6 } \\
\text { tahun }\end{array}$ & 0.75 & Valid \\
\hline 6 & Kesesuaian dengan tujuan pembelajaran literasi anak usia 5-6 tahun & 1 & Valid \\
\hline
\end{tabular}

Tabel 3. Hasil Validasi Ahli Media pada Aspek Kebahasaan

\begin{tabular}{clcc}
\hline No & \multicolumn{1}{c}{ Indikator } & Validitas Aiken & Kesimpulan \\
\hline 1 & Media big book mudah dipahami anak & 1 & Valid \\
\hline 2 & $\begin{array}{l}\text { Media big book memberikan pengerahuan tentang literasi anak usia } \\
\text { 5-6 tahun }\end{array}$ & 0.75 & \multirow{2}{*}{ Valid } \\
\hline 3 & Kesesuaian isi materi big book dengan kaidah Bahasa Indonesia & 0.75 & Valid \\
\hline 4 & Penggunaan bahasa big book efektif dan efisien & 0.75 & Valid \\
\hline
\end{tabular}


Tabel 4. Hasil Validasi Ahli Media pada Aspek Sajian

\begin{tabular}{clccc}
\hline No & \multicolumn{1}{c}{ Indikator } & Validitas Aiken & Kesimpulan \\
\hline 1 & $\begin{array}{l}\text { Media big book meningkatkan pembelajaran literasi anak usia 5-6 } \\
\text { tahun }\end{array}$ & 1 & Valid \\
\hline 2 & Urutan penyajian big book sesuai materi literasi anak usia 5-6 tahun & 0.75 & Valid \\
\hline 3 & $\begin{array}{l}\text { Media big book dapat meningkatkan motivasi anak dalam } \\
\text { pembelajaran literasi }\end{array}$ & 1 & Valid \\
\hline 4 & $\begin{array}{l}\text { Media big book dapat meningkatakan interaktivitas (stimulus dan } \\
\text { respon) }\end{array}$ & 0.75 & Valid \\
\hline 5 & $\begin{array}{l}\text { Media big book memberikan informasi tentang materi literasi anak } \\
\text { usia 5-6 tahun }\end{array}$ & 0.75 & Valid \\
\hline
\end{tabular}

Tabel 5. Hasil Validasi Ahli Media pada Aspek Kegrafisan

\begin{tabular}{llcc}
\hline No & \multicolumn{1}{c}{ Indikator } & Validitas Aiken & Kesimpulan \\
\hline 1 & Penggunaan font (jenis dan ukuran) dalam big book besar & 1 & Valid \\
\hline 2 & Tata letak gambar dan tulisan memperjelas materi literasi & 0.75 & Valid \\
\hline 3 & Ilustrai gabar memperjelas materi literasi & 0.75 & Valid \\
\hline 4 & Desan tampilan memperjelas materi big book & 0.75 & Valid \\
\hline
\end{tabular}

Tabel 6. Hasil Validasi Ahli Media pada Aspek Cover

\begin{tabular}{clcc}
\hline No & \multicolumn{1}{c}{ Indikator } & Validitas Aiken & Kesimpulan \\
\hline 1 & Judul sesuai dengan karakter anak usia 5-6 tahun & 1 & Valid \\
\hline 2 & Lay out dan tata letak memperjelas judul & 0.75 & Valid \\
\hline 3 & Desain judul sampul lebih menonjol daripada warna latarnya & 0.75 & Valid \\
\hline
\end{tabular}

Media big book pada aspek kelayakan isi, kebahasaan, sajian, kegrafisan dan cover disimpulkan memiliki validitas Aiken yang valid. Secara keseluruhan media big book pada aspek media dapat disimpulkan memiliki kualitas sangat baik.

\section{Hasil Penilaian Responden pada Uji Lapang Awal}

Tabel 7. Hasil Penilaian Responden pada Uji Lapang Awal

\begin{tabular}{clcc}
\hline No & \multicolumn{1}{c}{ Indikator } & Validitas Aiken & Kesimpulan \\
\hline 1 & Media big book mudah digunakan & 1 & Valid \\
\hline 2 & $\begin{array}{l}\text { Media big book dapat mempermudah pencapaian } \\
\text { pembelajaran }\end{array}$ & 1 & Valid \\
\hline 3 & Media big book menarik minat anak & 1 & Valid \\
\hline 4 & Media big book menciptakan rasa senang pada anak & 1 & Valid \\
\hline 5 & Media big book dapat digunakan secara berulang-ulang & 1 & Valid \\
\hline 6 & Media big book dapat menciptakan motivasi belajar anak & 1 & Valid \\
\hline 7 & Media big book membantu anak memahami informasi & 1 & Valid \\
\hline 8 & Kemampuan media dalam memicu kreativitas anak & 1 & Valid \\
\hline 9 & $\begin{array}{l}\text { Media big book dapat mengaktifkan anak dalam membangun } \\
\text { pengetahuan sendiri }\end{array}$ & 1 & Valid \\
\hline 10 & Media big book sesuai dengan dunia anak & Valid \\
\hline
\end{tabular}

Jadi media big book pada uji lapangan awal disimpulkan memiliki validitas Aiken yang valid. Hasil diskusi dan wawancara dengan responden dapat dideskripsikan sebagai berikut media big book sangat tepat untuk pembeajaran di TK B untuk memicu anak dalam belajar membaca namun perlu penambahan kegiatan untuk anak setelah menggunakan media big book. Dengan demikian dapat disimpulkan bahwa media big book ini sudah sangat relevan untuk pembelajaran di TK B 
Pengembangan Media Big Book Untuk Meningkatkan Kemampuan Literasi Anak Usia 5-6 Tahun (Gunanti Setiyaningsih, Amir Syamsudin)

\section{Hasil Penilaian Responden pada Uji Lapang Utama}

Tabel 8. Hasil Penilaian Responden pada Uji Lapang Utama

\begin{tabular}{clccc}
\hline No & \multicolumn{1}{c}{ Indikator } & Validitas Aiken & Kesimpulan \\
\hline 1 & Media big book mudah digunakan & 0.82 & Valid \\
\hline 2 & $\begin{array}{l}\text { Media big book dapat mempermudah pencapaian } \\
\text { pembelajaran }\end{array}$ & tujuan & 0.79 & Valid \\
\hline 3 & Media big book menarik minat anak & 0.82 & Valid \\
\hline 4 & Media big book menciptakan rasa senang pada anak & 0.86 & Valid \\
\hline 5 & Media big book dapat digunakan secara berulang-ulang & 0.75 & Valid \\
\hline 6 & Media big book dapat menciptakan motivasi belajar anak & 0.82 & Valid \\
\hline 7 & Media big book membantu anak memahami informasi & 0.76 & Valid \\
\hline 8 & Kemampuan media dalam memicu kreativitas anak & 0.86 & Valid \\
\hline 9 & $\begin{array}{l}\text { Media big book dapat mengaktifkan anak dalam membangun } \\
\text { pengetahuan sendiri }\end{array}$ & 0.86 & \multirow{2}{*}{ Valid } \\
\hline 10 & Media big book sesuai dengan dunia anak & 0.93 & Valid \\
\hline
\end{tabular}

Jadi media big book pada uji lapangan utama disimpulkan memiliki validitas Aiken yang valid. Data di atas diperkuat dengan hasil diskusi dan wawancara antara pengembang dengan responden. Hasil diskusi dan wawancara tersebut dapat dideskripsikan sebagai berikut media big book terus dapat digunakan secara terus menerus sebagia alat peraga sebab mudah dipahami anak dan menarik, media big book bisa menambah perbendaharaan kata dan pengetahuan anak.

\section{Hasil Kesepakatan Responden pada Uji Lapang Utama}

Pada uji lapang utama, penilaian dilakukan oleh 6 responden guru TK yang ada di Kecamatan Bambanglipuro Bantul.

Tabel 9. Hasil Kesepakatan Guru pada Uji Lapangan Utama

\begin{tabular}{ccc}
\hline No & Pasangan & Agreement $\mathbf{\%})$ \\
\hline 1 & G1-G2 & 40 \\
\hline 2 & G1-G3 & 70 \\
\hline 3 & G1-G4 & 70 \\
\hline 4 & G1-G5 & 50 \\
\hline 5 & G1-G6 & 50 \\
\hline 6 & G2-G3 & 50 \\
\hline 7 & G2-G4 & 50 \\
\hline 8 & G2-G5 & 50 \\
\hline 9 & G2-G6 & 40 \\
\hline 10 & G3-G4 & 100 \\
\hline 11 & G3-G5 & 20 \\
\hline 12 & G3-G6 & 60 \\
\hline 13 & G4-G5 & 20 \\
\hline 14 & G4-G6 & 60 \\
\hline 15 & G5-G6 & 20 \\
\hline & Jumlah & 750 \\
\hline & Agreement & 50 \\
\hline & Kategori & Cukup (moderate $)$ \\
\hline
\end{tabular}

Berdasarkan pada tabel 9, kesepakan rata-rata 6 guru diperoleh nilai koefisien Kappa $(K)=$ $50 \%$ dapat dikatakan bahwa kesepakatan 6 guru pada uji lapang utama memiliki tingkat kesepakatan yang cukup kuat dalam menilai kelayakan media big book dalam pembelajaran literasi anak yang dikembangkan. 


\section{Hasil Penilaian Responden pada Uji Lapang Diperluas}

Tabel 10. Hasil Penilaian Responden pada Uji Lapang Diperluas

\begin{tabular}{clccc}
\hline No & \multicolumn{1}{c}{ Indikator } & Validitas Aiken & Kesimpulan \\
\hline 1 & Media big book mudah digunakan & 0.85 & Valid \\
\hline 2 & $\begin{array}{l}\text { Media big book dapat mempermudah pencapaian } \\
\text { pembelajaran }\end{array}$ & tujuan & 0.83 & Valid \\
\hline 3 & Media big book menarik minat anak & 0.85 & Valid \\
\hline 4 & Media big book menciptakan rasa senang pada anak & 0.85 & Valid \\
\hline 5 & Media big book dapat digunakan secara berulang-ulang & 0.85 & Valid \\
\hline 6 & Media big book dapat menciptakan motivasi belajar anak & 0.79 & Valid \\
\hline 7 & Media big book membantu anak memahami informasi & 0.79 & Valid \\
\hline 8 & Kemampuan media dalam memicu kreativitas anak & 0.79 & Valid \\
\hline 9 & $\begin{array}{l}\text { Media big book dapat mengaktifkan anak dalam membangun } \\
\text { pengetahuan sendiri }\end{array}$ & \multirow{2}{*}{ Valid } \\
\hline 10 & Media big book sesuai dengan dunia anak & 0.85 & Valid \\
\hline
\end{tabular}

Jadi media big book pada uji lapangan diperluas disimpulkan memiliki validitas Aiken yang valid. Hasil diskusi dan wawancara tersebut dapat dideskripsikan sebagai berikut media big book menjadi salah satu media yang dapat meningkatkan pembelajaran literasi anak, sangat mudah digunakan, sesuai dengan dunia anak, sangat cocok untuk usia 5-6 tahun dan dapat membantu anak dalam latihan mengenal huruf, memberi semangat anak dalam belajar dan praktis

\section{Hasil Kesepakatan Responden pada Uji Lapang Diperluas}

Tabel 11. Hasil Kesepakatan Guru pada Uji Lapang Diperluas

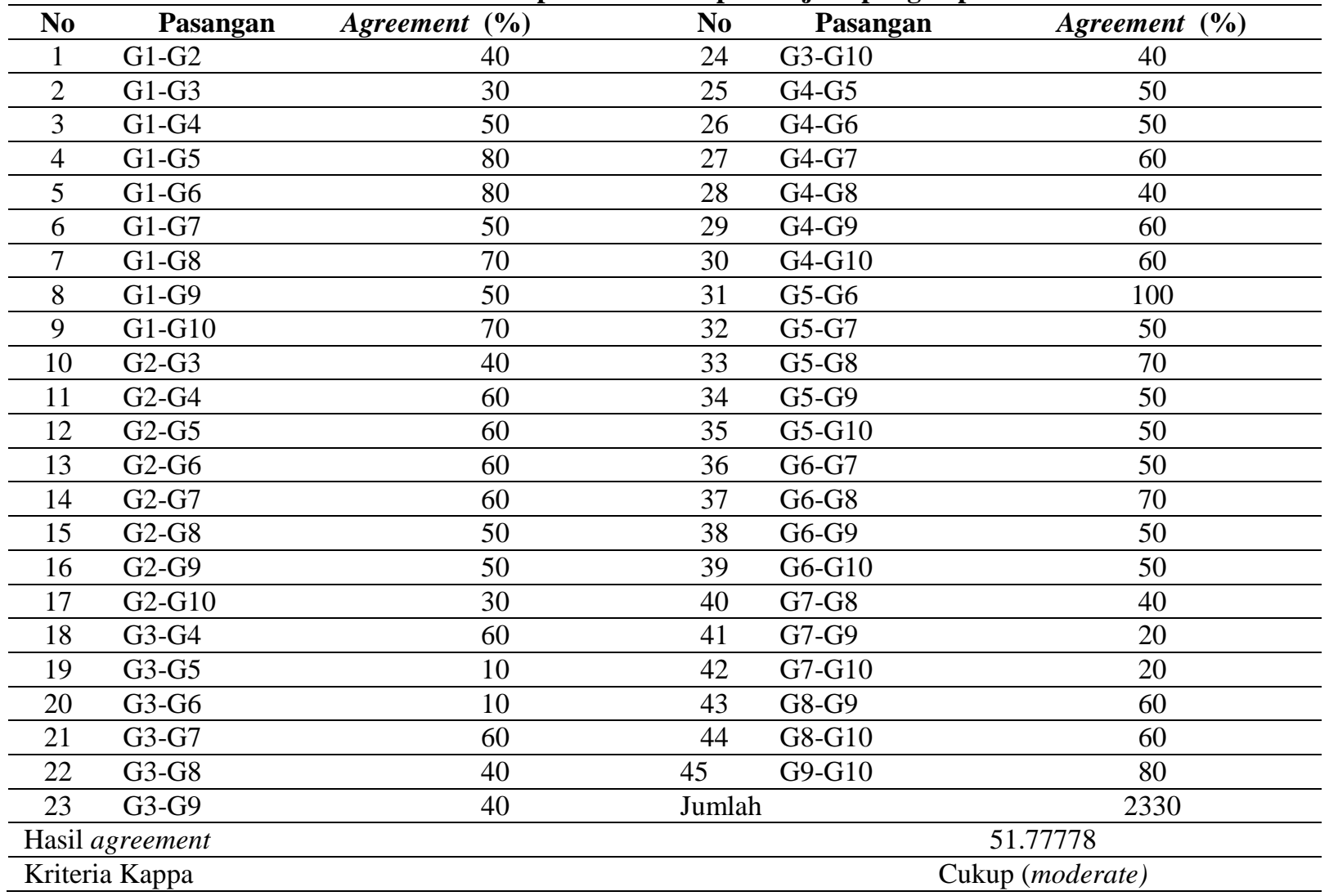

Berdasarkan data pada tabel 11, kesepakan rata-rata 10 guru diperoleh nilai koefisien Kappa $(\mathrm{K})=51,78 \%$ dapat dikatakan bahwa kesepakatan 10 guru pada uji lapangan diperluas memiliki tingkat kesepakatan yang cukup kuat dalam menilai kelayakan media big book dalam pembelajaran literasi anak. 
Pengembangan Media Big Book Untuk Meningkatkan Kemampuan Literasi Anak Usia 5-6 Tahun (Gunanti Setiyaningsih, Amir Syamsudin)

\section{Kemampuan Literasi Anak Pada Uji Lapang Diperluas}

Tabel 12. Kemampuan Literasi Anak pada Uji Lapang Diperluas

\begin{tabular}{llc}
\hline No & \multicolumn{1}{c}{ Kategori } & Frekuensi \\
\hline 1 & Belum berkembang (BB) & 0 \\
\hline 2 & Mulai berkembang (MB) & 16 \\
\hline 3 & Berkembang sesuai harapan (BSH) & 69 \\
\hline 4 & Berkembang sangan baik (BSB) & 105 \\
\hline
\end{tabular}

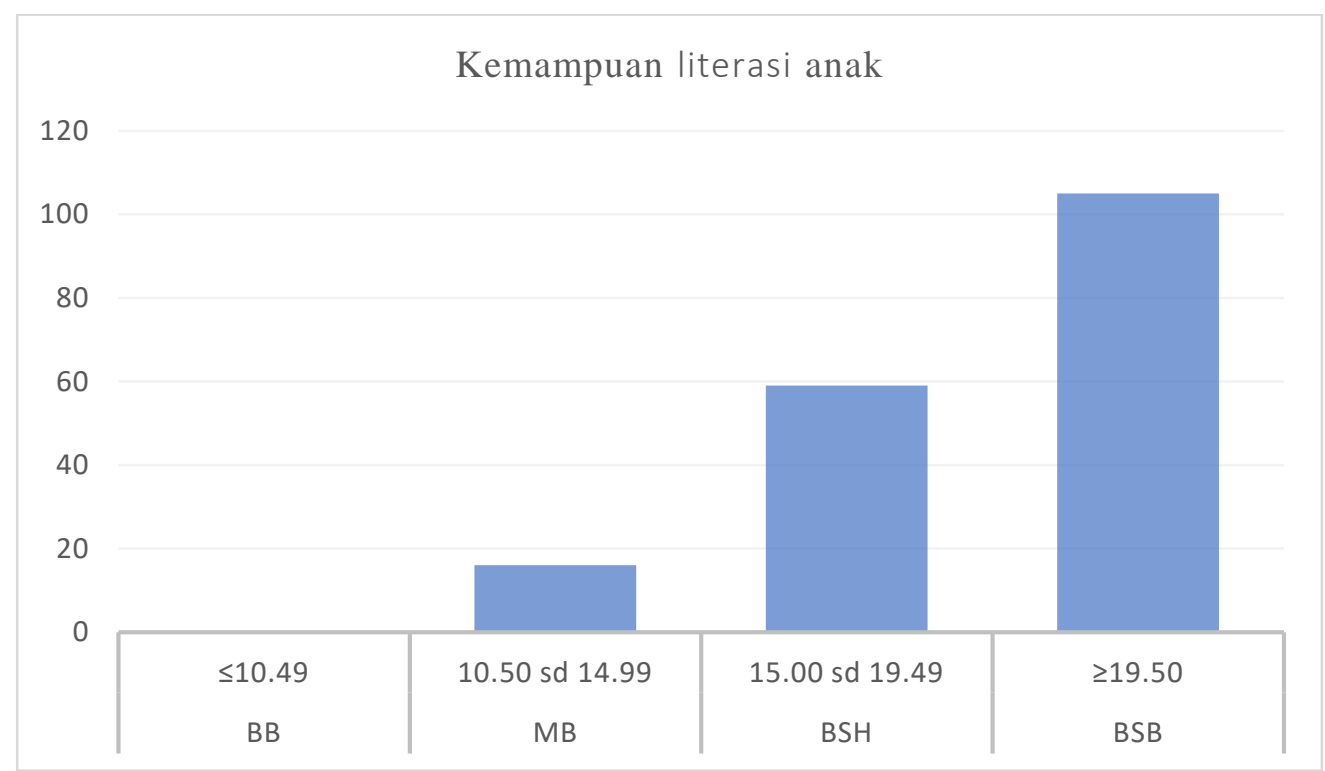

Grafik 1. Kemampuan Literasi Anak pada Uji Lapang Diperluas

Berdasarkan data pada grafik 1 tersebut kemampuan literasi anak pada uji lapangan diperluas dengan kategori MB berjumlah 16 anak, BSH berjumlah 59 anak dan BSB berjumlah 105 anak. Kemampuan literasi rata-rata berada pada kategori berkembang sangat baik. Dengan demikian produk akhir media big book untuk meningkatkan kemampuan literasi anak usia 5-6 tahun sesuai dengan tujuan pengembangan media big book.

\section{Pembahasan}

Big book adalah buku yang berukuran besar yang dilengkapi dengan teks dan gambar berukuran besar sehingga memudahkan anak dalam mengamati setiap huruf maupun simbol yang terdapat dalam buku tersebut. Big book juga dilengkapi dengan gambar yang penuh warna dan alur cerita yang jelas. Ciri-ciri big book berdasarkan para ahli adalah berukuran besar $40 \mathrm{~cm} \times 60 \mathrm{~cm}$, memuat gambar dan tulisan yang besar, warna-warni, terdiri dari 10-15 halaman, gambar memiliki makna, pola kata-kata berulang, jenis dan ukuran huruf jelas, alur cerita sederhana dan mudah dipahami anak. Adapun keistimewaan big book adalah memberikan kesempatan pada anak untuk terlibat dalam situasi nyata dengan cara yang menyenangkan, mengembangkan semua aspek kebahasaan dan pengalaman sosial anak, disukai anak, meningkatkan motivasi dan keaktifan anak.

Big book yang dikembangkan setelah melewati tahapan evaluasi produk, baik uji kelayakan terbatas dari ahli materi dan ahli media, maupun uji coba produk yang meliputi uji lapangan awal, uji lapangan utama dan uji lapangan diperluas, produk media big book hasil pengembangan tersebut sudah layak menjadi produk akhir yang dapat disebarluaskan dan diimplementasikan kepada para pengguna. Sesuai dengan kategori kualitas produk media big book yang telah ditetapkan, yaitu bahwa setiap aspek yang dinilai dalam produk yang dikembangkan dianggap layak jika semua penilai menilai kualitas produk minimal dengan kategori cukup baik, maka media big book dianggap layak sebagai media pembelajaran baik dari segi tampilan produk maupun aspek kualitas produk. Hasil produk pengembangan big book sesuai dengan pendapat Tompkins \& Hoskisson (1995); Jalongo (2007); Curtain \& Dahbelrg (2010); Hall \& O'Connor (2006) yang menyatakan bahwa big book 
berukuran cukup besar dengan tulisan besar dan gambar yang terlihat jelas yang digunakan untuk kegiatan membaca bersama dan dapat dilihat oleh seluruh anak di kelas.

Berdasarkan pengamatan uji coba produk kepada anak terungkap bahwa proses pembelajaran literasi dengan menggunakan media big book memudahkan anak dalam memahami materi literasi, menyenangkan, menarik, memotivasi anak, tidak membosankan, menjadikan anak lebih aktif dan antusias. Hal ini sesuai dengan pendapat Yaacob \&Pinter (2008) yang menyatakan bahwa big book meningkatkan motivasi, ketertarikan anak, partisispasi dan keaktifan anak dalam belajar. Senada juga dengan pendapat Lynch (2008) yang menyatakan bahwa big book menjadi motivasi yang kuat untuk belajar tentang pengucapan kata, bentuk dan jenis kata majemuk, kata kerja, singkatan maupun sajak.

Produk akhir media big book untuk meningkatkan kemampuan literasi anak usia 5-6 tahun sesuai dengan tujuan pengembangan media big book. Hal ini sesuai dengan pendapat Ningpramesthi (2014), Puspaningrum (2015), Nurkhasanah (2016), Halimatussa'diyah (2017) dan Septiyanin (2017) yang menyatakan bahwa penggunaan media big book dapat mempengaruhi kemampuan literasi anak.

\section{SIMPULAN DAN SARAN}

Berdasarkan pendapat ahli materi literasi, media big book yang dikembangkan memiliki validitas Aiken yang cukup valid. Penilaian media big book yang dikembangkan menurut ahli media sudah sangat baik dilihat dari aspek kelayakan isi, kebahasaan, sajian, kegrafisan dan cover. Selain itu, penilaian media big book pada uji lapangan awal, uji lapangan utama dan uji lapangan diperluas memiliki validitas Aiken yang valid. Hasil kesepakatan guru pada uji lapangan utama dan uji lapangan diperluas berada pada kategori moderate (cukup).

Media big book yang dikembangkan dapat digunakan setiap hari pada TK kelompok B selama 5-10 menit untuk pembelajarn literasi dengan mengenalkan huruf maupun kata yang terdapat dalam media big book.

\section{UCAPAN TERIMAKASIH}

Terima kasih banyak kami ucapkan kepada Direktur Pascasarjana Universitas Negeri Yogyakarta, Kaprodi S2 PAUD UNY dan guru-guru TK se-Kecamatan Bambanglipuro Bantul.

\section{DAFTAR PUSTAKA}

Biddle, K.A.G, et al. (2014). Early chilhood education becoming a professional. California: Sage Publications,Inc.

Boove, C. (1997). Business communication today. New York: Prentice Hall.

Borg, W.R \& Gall, M.D. (1983). Educational research an introduction (fourth edition). New York \& London: Longman.

Brewer, J. (2014)). Introduction to early chilhood education: preschool through primary grades. England; Pearson Education Limited sixth edition.

Brown, E. (1980). The bases of reading acquisition. Reading research.

Colville- H, S \& O'Connor, B. (2006). Using bog book: a standards-based instructional approach for foreign language teacher candidate in preK-12 program. Foreign Language Annals, 39 (3), 487-506.

Flewitt, R. (2011). Bringing etnography to a multimodal investigation of early literacy in a digital age. Qualitative Research II (3),293-310

Gagne, R.M. \& Briggs, L.J. (1979). Principles of Instructional Design. New Yorks: Holt Rinehart and Winston.

Goodman, K.S. (1986). What's whole in whole language?. Portsmouth, NH: Heinemann

Halimatussa'diyah. (2017). Pengembagan media big book untuk menstimulasi kemampuan membaca permulaan anak kelompok B PAUD Tanwirul Qulub tahun ajaran 2016/2017. Cakrawala Dini Volume 8 Nomor 2 
Pengembangan Media Big Book Untuk Meningkatkan Kemampuan Literasi Anak Usia 5-6 Tahun

(Gunanti Setiyaningsih, Amir Syamsudin)

Heinich, R.,et al. (1996). Instructional media and technologies for learning. New Jersey: Prentice Hall, Englewood Cliffs.

Jalongo, M.R. (2007). Early chilhood language arts. USA: Pearson Education, Inc.

Jamaris, M. (2006). Perkembangan dan pengembangan anak usia taman kanak-kanak. Jakarta: Grasindo.

Karges, L \& Bone. (1992). Bring on the big books. The reading teacher

Lynch, P. (2008). Using big books and predictable books. Scholastic: Canada Ltd.

Mena, J.G \& Eyer, D.W. (2009). Infants, toddlers and caregivers a curriculum of respectful, responsive care and education eigth edition. New York: The MCGraw-Hill Companies,Inc.

Meyer,E.R. (2008). Learning and instruction. Second edition. Upper sadle river, N.J: Pearson Merill Prentice.

Ningpramesthi. (2014). Peningkatan kemampuan literasi melalui pemanfaatan media big book cerita pengalaman pada siswa kelas II SDN popoh 03 Kabupaten Blitar. Fakultas Ilmu Pendidikan. Universitas Negeri Malang. Skripsi

Normaliza, A.R \& Nik, I.H. (2010). Student's perception towards the usage of the big book. Gading Business and Mangement Journal Vol.14.

Nurkhasanah. (20160. Upaya meningkatkan kemampuan mengungkapkan bahasa melalui metode bercerita dengan media big book di PAUD Al Muttaqien Sukabumi Bnadar Lampung. Fakultas Keguruan dan Ilmu pendidikan. Universitas Lampung. Skripsi

Pilgrim, J \& Martinez, E. E. (2013). Defining literacy in the 21 st century: a guide to terminology and skills. Texas Journal of Literacy Education Vol.1 Issues 1.

Puspaningrum. (2015). Pengaruh penggunaan media big book terhadap kemampuan literasi informasi siswa Sekolah Dasar. Universitas Negeri Surabaya: JPGSD Volume 3 Nomor 2

Sadiman, A. (2014). Media pendidikan. Jakarta: PT RajaGrafindo Persada.

Santrock. (2007). Perkembangan masa hidup. (Terjemahan: Chusairi, A \& Sinaga, H).Jakarta: Erlangga

Septiyani, S. (2017). Pengaruh Media big book terhadap kemampuan bicara nak usia dini. PG-PAUD FKIP UNIB: Jurnal Potensia Volume 2 Nomor 1

Solehuddin, dkk. (2009). Pembaharuan pendidikan TK. Jakarta: Universitas Terbuka.

Suyanto, S. (2005). Dasar-dasar pendidikan anak usia dini. Yogyakarta: Hikayat Publishing

Suyanto, K. (2007). English for young leaners. Jakarta: PT Bumi Aksara.

Tompkins, G. E \& Hoskisson, K. (1995). Language arts content and teaching strategies. USA: Prentice-Hall, Inc.

Thomkkins, G. (2001). Literacy for the 21st century: a balanced approach 2nded. Upper Saddle River, NJ: Merill Prentice Hall.

Walker, D.F \& Hess, R.D. (1984). Instructional software: principle and perspectives for design and use. California: Wadsworth, Inc.

Yaacob, A \& Pinter, A. (2008). Exploring the effectiveness of using big books in teaching primary english in malaysian classrooms. MJLI Vol 5. 